\title{
Degree of pollution by benthic litter in beaches in Salvador, Bahia, Brazil
}

\author{
G. Fernandino ${ }^{1}$; C. I. Elliff ${ }^{1}$; I. R. Silva ${ }^{2}$ \\ 1 Curso de Pós-Graduação em Geologia - Instituto de Geociências, Universidade Federal da \\ Bahia, Rua Barão de Geremoabo, s/n, Campus Federação, CEP 40170-290, Salvador, Bahia, Brazil. \\ ${ }^{2}$ Departamento de Oceanografia - Instituto de Geociências, Universidade Federal da Bahia, Rua Barão de \\ Geremoabo, s/n, Campus Federação, CEP 40170-290, Salvador, Bahia, Brazil.
}

gerson.fernandino@yahoo.com.br

(Recebido em 01 de dezembro de 2014; aceito em 06 de fevereiro de 2015)

\begin{abstract}
O lixo bentônico tem-se caracterizado como um problema não só para o meio ambiente, mas também para gestores, devido ao seu difícil acesso. Assim, pouco ainda se sabe sobre os impactos e comportamento dessa forma de poluição. O objetivo deste estudo foi realizar uma análise quali-quantitativa do lixo bentônico de três praias em Salvador, BA, Brasil, a fim de se realizar uma investigação quanto às fontes poluidoras e possíveis ações mitigadoras da situação. Foram realizadas três campanhas entre os anos de 2012 e 2013. Transectos medindo $100 \mathrm{~m}$ de comprimento foram colocados perpendicularmente à costa em cada praia e, utilizando equipamento de mergulho autônomo, todo o lixo bentônico foi coletado a uma distância de $1 \mathrm{~m}$ para cada lado do cabo-eixo. Todos os itens foram triados e analisados com relação ao tipo de material e possíveis fontes. O cálculo do CCI foi adaptado para classificar a parte submersa de cada praia e sua variância entre locais e datas foi analisada através do teste de Kruskal-Wallis. Durante esse período os pontos variaram entre muito limpos a extremamente sujos. Plástico foi o tipo de material mais comum e fatores como a proximidade com as possíveis fontes desse resíduo e a ação da hidrodinâmica tiveram um papel importante nos resultados encontrados. Não houve diferenças significativas entre locais e datas. Ações de conscientização da população que frequenta as praias são cruciais para mitigar a situação, visto que as fontes do lixo encontrado foram principalmente locais. Além disso, esforços de limpeza pública se mostraram ineficazes.
\end{abstract}

Palavras-chave: praia urbana; lixo bentônico; gerenciamento costeiro.

\section{Degree of pollution by benthic litter in beaches in Salvador, Bahia, Brazil}

Benthic litter has become a problem not only to the environment, but also to managers, due to its difficult access. Thus, little is still known about its impacts and behaviors as a type of pollution. The objective of the present study was to carry out a quali-quantitative analysis of the benthic litter of three beaches in Salvador, Brazil, so to investigate the sources of the pollution and possible mitigating actions. Three sampling campaigns were carried out between the years of 2012 and 2013. Transects measuring $100 \mathrm{~m}$ were placed perpendicularly to the coastline at each beach and, using scuba diving equipment, all benthic litter was gathered up to $1 \mathrm{~m}$ to each side of the axis cable. All items were sorted and analyzed regarding the type of material and possible sources. An adapted CCI was used to classify each beach and variance was analyzed through the Kruskal-Wallis test among sites and dates. During this period the beaches varied from very clean to extremely dirty regarding the accumulation of benthic litter. Plastic was the most common type of material and factors such as proximity with possible sources of pollution and hydrodynamics played an important role in the observed results. There were no significant differences among sites and dates. Actions to promote public awareness among the population that frequents these beaches are crucial to mitigate the situation, considering that the main litter sources were local. Moreover, current public beach cleaning efforts have shown to be ineffective.

Keywords: urban beach; benthic litter; coastal management.

\section{INTRODUCTION}

Since the 1970's, scientists have encountered litter on the seafloor in coastal and oceanic regions, especially through opportunistic samplings, in which litter was gathered using bottom trawl nets when sampling for organisms $[1,2,3,4,5]$. Once in the ocean, heavier items can 
sink and impact the benthic ecosystem. Even lighter items that tend to float can be deposited on the bottom when their mass increases as a consequence of absorption of water or other substances, as well as the incrustation of living organisms [6]. Plastics compose most of the litter found in the marine environment as a whole and, although they are less dense and tend to float, when they are either incrusted by sessile organisms or when they accumulate sand and other debris, they can reach the seafloor [7].

Although marine litter is present in all oceans, it can be found in higher concentrations in the proximities of large urban centers [5]. However, litter is not restricted to these regions, because its distribution is subjected to hydrodynamic circulation patterns and to the presence of obstacles on the bottom that can retain and accumulate objects [4].

The operational difficulty usually involved in benthic samplings can often limit the performance of studies on this theme. Moreover, the reduced appeal of this type of pollution, since it is not usually seen by the population, leads to a false impression of the health status of the environment.

The municipality of Salvador, capital of the state of Bahia, is a metropolis with a population of over 2.6 million inhabitants [8]. The beaches of the municipality, particularly those in the Barra neighborhood, attract tourists due to their natural beauty and historical and cultural relevance. Thus, this region can be considered as one of the most important touristic points in the municipality. The sand strip and, consequently, the sea of these beaches are widely used by bathers, be them either tourists or residents. The presence of a great variety of structures and benthic ecosystems, with consolidated substrate and a great density of sessile invertebrates, attracts artisanal and recreational fishermen, as well as divers, because this congregates fish and invertebrates. In addition to these users, there are many salespeople walking along the beach and beach tents that sell food and beverages. These can be considered important contributors for generating solid residues.

Another factor that potentially contributes to the input of litter in the marine environment of the Barra beaches is the presence of rainwater drainage pipes that, together with the water, carry residues that were inadequately discarded on the streets of the municipality.

Santana Neto et al. [9] evaluated the perception of the beach users at the Porto da Barra beach, located in the Barra neighborhood, regarding the presence of marine litter. According to the interviews that were carried out on this beach, approximately $85 \%$ of the users considered the Porto da Barra beach to be dirty. The interviewees also indicated that the lack of awareness/education and unavailability of trash cans were the main factors that contribute to the presence of litter on the beach. These authors also emphasize the importance of this theme to the municipality, since the occurrence of litter can affect marine organisms and the economy of sectors such as fisheries and tourism, compromising the local esthetic quality $[9,10,11]$.

Evaluating the quantity, types, distribution and sources of marine litter is important to aid the development of control and mitigation strategies [11].

Thus, the objective of the present study was to evaluate the degree of pollution by benthic litter in three beaches in Salvador based on the number of debris found on the seafloor.

\section{MATERIAL AND METHODS}

The benthic litter of three beaches in the Barra neighborhood in the municipality of Salvador, Bahia, was gathered during cleaning activities using scuba diving equipment. Several studies have applied this methodology in the sampling and assessment of benthic litter in coastal regions $[12,13,14,15]$ due to its efficiency and precision. It also has the distinct advantage that it can be used on any type of bottom, considers even smaller items of litter and does not cause alterations to the environment, as reported by Spengler and Costa [11]. According to these authors, the limitations in using this methodology are regarding the length of time, depth and size of the area studied.

The Porto da Barra, Hospital Espanhol and Farol da Barra beaches were chosen due to their appeal to the local and tourist populations, considering that they are intensely used by bathers 
and other users, such as salespeople, for example. The location of these beaches and of the sampling stations is illustrated in Figure 1.

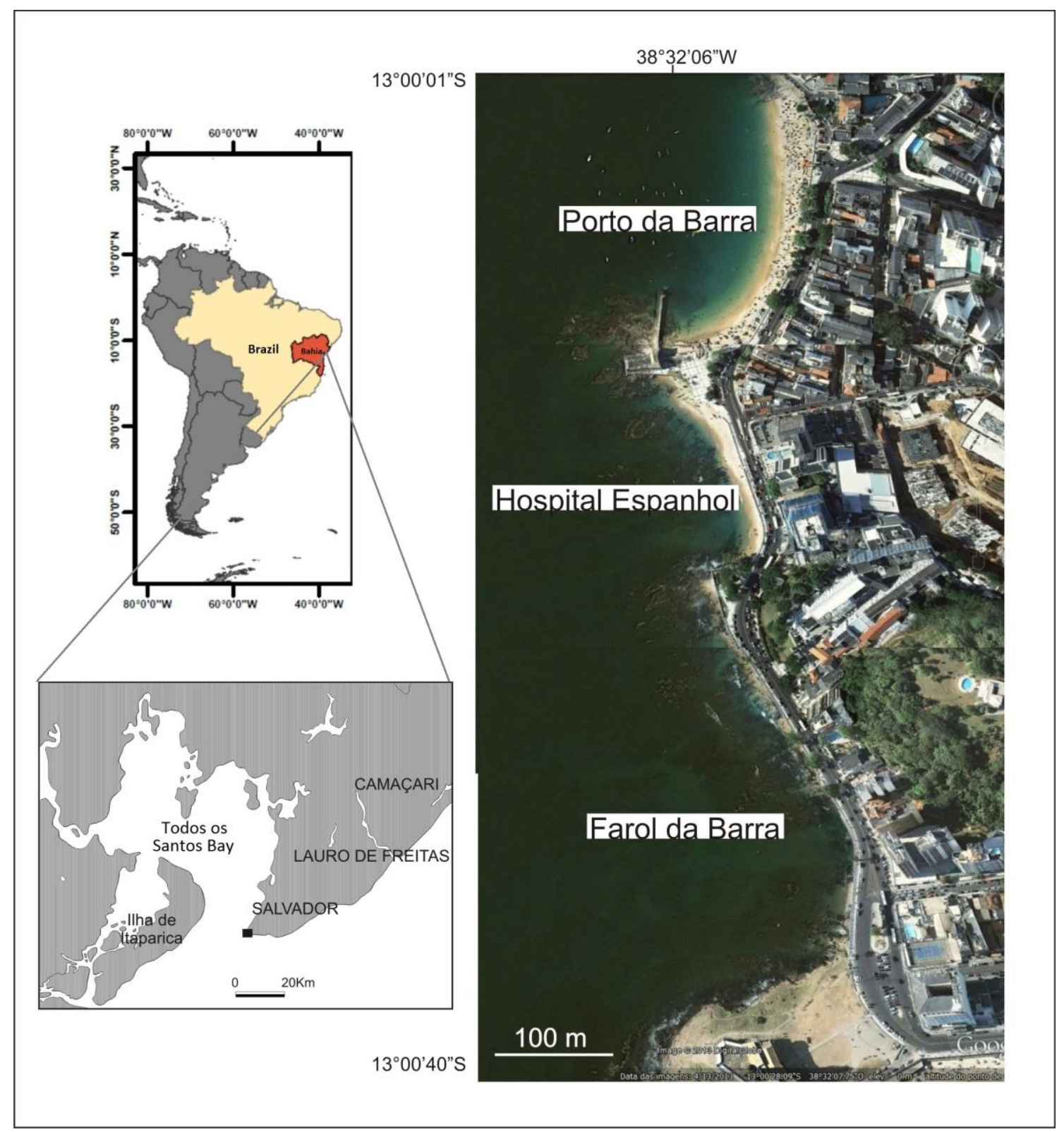

Figure 1: Location of the area studied and of the sampling stations.

The depths of the sampled locations varied between 2 and $10 \mathrm{~m}$ and the seafloor consisted of either unconsolidated or consolidated substrate, which could be covered or not by sediment. The following criteria was used to select the transects: mixed composition of substrate (so to avoid places composed exclusively by sand); availability of a continuous linear length of at least $100 \mathrm{~m}$ to place the transect perpendicularly to the beach; depth of up to $10 \mathrm{~m}$ (diver safety).

Three benthic litter sampling campaigns were carried out in each beach between the years of 2012 and 2013. The first was on September 22 ${ }^{\text {nd }}, 2012$ (Coastal Clean-Up Day), the second campaign was on February $6^{\text {th }}, 2013$ (one day before Carnaval), and the third was on February 14th, 2013 (one day after the end of the Carnaval festivities in the city). It is important to emphasize that the Carnaval festivities in the municipality of Salvador are of very large proportions, attracting thousands of people from all over the country and abroad to the Barra region. 
The sampling methodology was adapted from Cheshire et al. [16]. The samplings were performed along a $100 \mathrm{~m}$-long transect placed perpendicularly to the coastline in each beach, with buoys on each extremity, indicating its beginning and end for safety reasons for the divers (Figure 2).

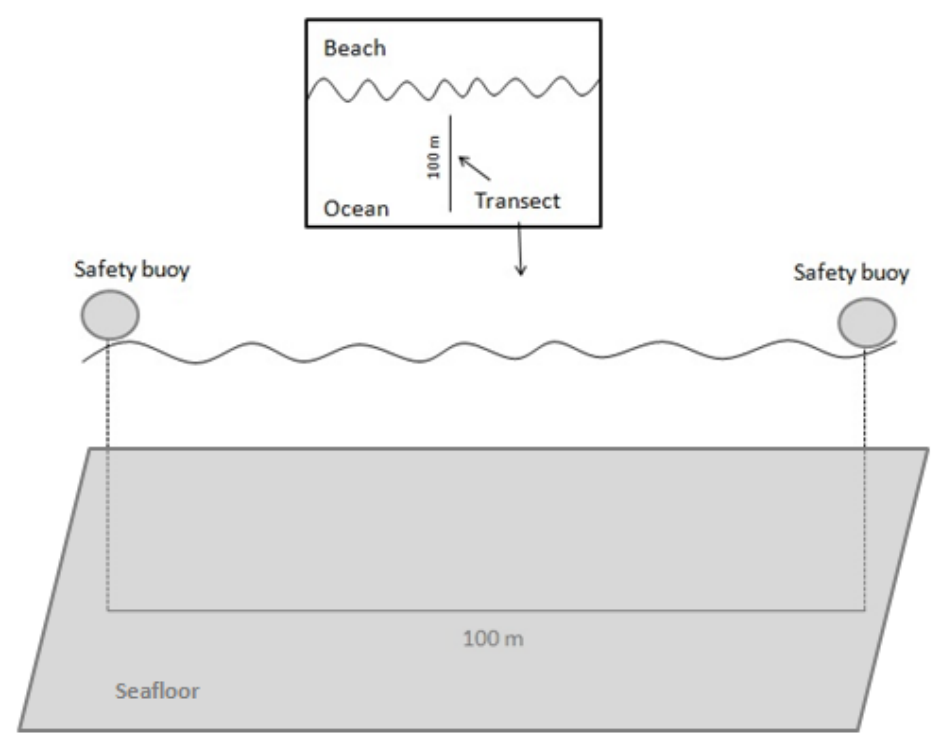

Figure 2: Sketch of the transect methodology used.

Each transect was designated to two divers that received specific training for the activity. Their role was to gather all the litter found at a distance of up to $1 \mathrm{~m}$ to each side of the central cable of the transect. Items that had 50\% or more of their surface incrusted by organisms were not removed, since these were considered to have been incorporated to the environment. Thus, with a known sampling area $\left(200 \mathrm{~m}^{2} /\right.$ transect $)$, it was possible to calculate the density of items found (No. items $/ \mathrm{m}^{2}$ ).

All the litter removed during the activities was duly identified, sorted and then collected by a recycling cooperative that would recycle the materials that still presented conditions to do so. The remaining material (i.e. those that could not be recycled) was collected by the public municipal garbage service. The materials were classified according to their composition, based on the recommendation from the United Nations Environment Program (UNEP) [16], adding new sub-classes that described the type of material (e.g. plastic bag, beverage can, barbecue stick), according to the local reality so to assist in the identification of the sources. The primary classes were: plastic, foam, fabric, glass/ceramic, metal, paper, rubber, wood, and others.

The calculations and classification proposed by Alkalay et al. [17], which originated the Clean Coast Index (CCI), were used in the present study with the aim to classify the sampled locations according to their degree of pollution by solid residues - in other words, their cleanliness. Although the CCI only considers plastic items in its calculations, this index was modified in the present study so to consider all types of items, since plastic does not have the same representativeness in benthic environments. The same correction coefficient $(K=20)$ used in the CCI was applied here. Thus, the sampling points were classified as: very clean $(0-2)$; clean (2-5); moderate (5-10); dirty (10-20); and extremely dirty (> 20).

The variance among sampling stations and campaigns was analyzed through the Kruskal-Wallis test, using the BioEstat 5.3 software.

\section{RESULTS}

A total of 781 items was gathered. There was no statistically significant difference $(p>0.05)$ among beaches and among campaigns. February $6^{\text {th }}, 2013$, which was before Carnaval, was the day with the greatest number of items (416). The day after Carnaval, February $14^{\text {th }}, 2013$, 
presented the lowest values (40 items in total). Table 1 describes the total of items and the tide range variation.

Table 1: Tide range variation and total of items per beach on each sampling date.

\begin{tabular}{|c|c|c|c|c|c|c|}
\hline Date & $\begin{array}{c}\text { Porto da } \\
\text { Barra }\end{array}$ & $\begin{array}{c}\text { Hospital } \\
\text { Espanhol }\end{array}$ & $\begin{array}{c}\text { Farol da } \\
\text { Barra }\end{array}$ & $\begin{array}{c}\text { Total per } \\
\text { day }\end{array}$ & Tide & $\begin{array}{c}\text { Amplitude } \\
\text { (m) }\end{array}$ \\
\hline $09 / 22 / 2012$ & 108 & 91 & 126 & 325 & Neap/falling & 1.1 \\
\hline $02 / 06 / 2013$ & 253 & 145 & 18 & 416 & Neap/rising & 1.4 \\
\hline $02 / 14 / 2013$ & 30 & 0 & 10 & 40 & Spring/falling & 2.2 \\
\hline $\begin{array}{c}\begin{array}{c}\text { Total per } \\
\text { beach }\end{array} \\
\end{array}$ & 391 & 236 & 154 & 781 & & \\
\hline
\end{tabular}

Porto da Barra presented the highest mean occurrence of items (130.33 items), while the lowest mean was at Farol da Barra (51.33 items). Although the Hospital Espanhol (78.67 items) beach did not present any items on one of the sampling campaigns, it presented a relatively high mean of gathered items, surpassing the mean found at the Farol da Barra beach (Table 2).

Table 2: Means and standard deviations of the sampled beaches.

\begin{tabular}{ccccc}
\hline & Porto da Barra & $\begin{array}{c}\text { Hospital } \\
\text { Espanhol }\end{array}$ & Farol da Barra & Global \\
\hline $\begin{array}{c}\text { Mean } \\
\text { Standard } \\
\text { deviation }\end{array}$ & 130.33 & 78.67 & 51.33 & 260.33 \\
\hline
\end{tabular}

Considering the total number of items gathered in all three campaigns, the plastics category predominated in two of the three beaches: Hospital Espanhol (51.69\%) and Farol da Barra (68.18\%).

At the Porto da Barra beach, plastic (21.99\%) was surpassed only by the wood category $(47.57 \%)$. This difference can be attributed to the fact that this class was composed exclusively by barbecue and ice cream sticks, which are commonly consumed items at this location, indicating the source of this material. The Porto da Barra beach presented the greatest concentration of people and tents selling food and beverages, which are potential sources for this type of material.

At the Hospital Espanhol beach, plastic was followed by metal (37.71\%), represented mainly by aluminum cans, and then wood (4.24\%). At the Farol da Barra beach, plastic was followed by fabric (11.04\%) and metal (7.79\%). Tables 3, 4 and 5 present the abundance and percentage of marine litter found, divided in the nine categories adopted according to their composition. 
Table 3: Abundance and percentage of marine litter at Porto da Barra.

\begin{tabular}{|c|c|c|c|c|c|c|c|c|}
\hline \multirow{3}{*}{ Categories } & \multicolumn{8}{|c|}{ Porto da Barra } \\
\hline & \multicolumn{2}{|c|}{$09 / 22 / 2012$} & \multicolumn{2}{|c|}{$02 / 06 / 2013$} & \multicolumn{2}{|c|}{$02 / 14 / 2013$} & \multicolumn{2}{|c|}{ Total } \\
\hline & $\begin{array}{c}\text { No. } \\
\text { items }\end{array}$ & $\%$ & $\begin{array}{c}\text { No. } \\
\text { items }\end{array}$ & $\%$ & $\begin{array}{c}\text { No. } \\
\text { items }\end{array}$ & $\%$ & $\begin{array}{c}\text { No. } \\
\text { items }\end{array}$ & $\%$ \\
\hline Plastic & 35 & 32.41 & 41 & 16.21 & 10 & 33.33 & 86 & 21.99 \\
\hline Foam & 0 & 0 & 0 & 0 & 0 & 0 & 0 & 0 \\
\hline Fabric & 6.00 & 5.56 & 6.00 & 2.37 & 6.00 & 20.00 & 18.00 & 4.60 \\
\hline Glass/Ceramic & 4 & 3.7 & 4 & 1.58 & 1 & 3.33 & 9 & 2.3 \\
\hline Metal & 24 & 22.22 & 33 & 13.04 & 6 & 20 & 63 & 16.11 \\
\hline Paper & 7 & 6.48 & 5 & 1.98 & 7 & 23.33 & 19 & 4.86 \\
\hline Rubber & 1.00 & 0.93 & 3.00 & 1.19 & 0 & 0 & 4.00 & 1.02 \\
\hline Wood & 27 & 25 & 159 & 62.85 & 0 & 0 & 186 & 47.57 \\
\hline Others & 4 & 3.7 & 2 & 0.79 & 0 & 0 & 6 & 1.53 \\
\hline
\end{tabular}

Table 4: Abundance and percentage of marine litter at Hospital Espanhol.

\begin{tabular}{|c|c|c|c|c|c|c|c|c|}
\hline \multirow{3}{*}{ Categories } & \multicolumn{8}{|c|}{ Hospital Espanhol } \\
\hline & \multicolumn{2}{|c|}{$09 / 22 / 2012$} & \multicolumn{2}{|c|}{$02 / 06 / 2013$} & \multicolumn{2}{|c|}{$02 / 14 / 2013$} & \multicolumn{2}{|c|}{ Total } \\
\hline & $\begin{array}{c}\text { No. } \\
\text { items }\end{array}$ & $\%$ & $\begin{array}{l}\text { No. } \\
\text { items }\end{array}$ & $\%$ & $\begin{array}{l}\text { No. } \\
\text { items }\end{array}$ & $\%$ & $\begin{array}{c}\text { No. } \\
\text { items }\end{array}$ & $\%$ \\
\hline Plastic & 34 & 37.36 & 88 & 60.69 & 0 & 0 & 122 & 51.69 \\
\hline Foam & 0 & 0 & 0 & 0 & 0 & 0 & 0 & 0 \\
\hline Fabric & 7.00 & 7.69 & 1.00 & 0.69 & 0 & 0 & 8.00 & 3.39 \\
\hline Glass/Ceramic & 0 & 0 & 0 & 0 & 0 & 0 & 0 & 0 \\
\hline Metal & 41 & 45.05 & 48 & 33.1 & 0 & 0 & 89 & 37.71 \\
\hline Paper & 3 & 3.3 & 0 & 0 & 0 & 0 & 3 & 1.27 \\
\hline Rubber & 1.00 & 1.10 & 1.00 & 0.69 & 0 & 0 & 2.00 & 0.85 \\
\hline Wood & 3 & 3.3 & 7 & 4.83 & 0 & 0 & 10 & 4.24 \\
\hline Others & 2 & 2.2 & 0 & 0 & 0 & 0 & 2 & 0.85 \\
\hline
\end{tabular}

Table 5: Abundance and percentage of marine litter at Farol da Barra.

\begin{tabular}{|c|c|c|c|c|c|c|c|c|}
\hline \multirow{3}{*}{ Categories } & \multicolumn{8}{|c|}{ Farol da Barra } \\
\hline & \multicolumn{2}{|c|}{ 09/22/2012 } & \multicolumn{2}{|c|}{$02 / 06 / 2013$} & \multicolumn{2}{|c|}{$02 / 14 / 2013$} & \multicolumn{2}{|c|}{ Total } \\
\hline & $\begin{array}{c}\text { No. } \\
\text { items }\end{array}$ & $\%$ & $\begin{array}{l}\text { No. } \\
\text { items }\end{array}$ & $\%$ & $\begin{array}{l}\text { No. } \\
\text { items }\end{array}$ & $\%$ & $\begin{array}{l}\text { No. } \\
\text { items }\end{array}$ & $\%$ \\
\hline Plastic & 90 & 71.43 & 12 & 66.67 & 3 & 30 & 105 & 68.18 \\
\hline Foam & 0 & 0 & 0 & 0 & 0 & 0 & 0 & 0 \\
\hline Fabric & 16.00 & 12.70 & 1.00 & 5.56 & 0 & 0 & 17.00 & 11.04 \\
\hline Glass/Ceramic & 3 & 2.38 & 1 & 5.56 & 0 & 0 & 4 & 2.6 \\
\hline Metal & 11 & 8.73 & 0 & 0 & 1 & 10 & 12 & 7.79 \\
\hline Paper & 1 & 0.79 & 3 & 16.67 & 6 & 60 & 10 & 6.49 \\
\hline Rubber & 1.00 & 0.79 & 0 & 0 & 0 & 0 & 1.00 & 0.65 \\
\hline Wood & 1 & 0.79 & 0 & 0 & 0 & 0 & 1 & 0.65 \\
\hline Others & 3 & 2.38 & 1 & 5.56 & 0 & 0 & 4 & 2.6 \\
\hline
\end{tabular}


The classification of the beaches regarding their degree of cleanliness or pollution by solid residues varied between the both extremities of the gradient, going from very clean (Farol da Barra on the $2^{\text {nd }}$ and $3^{\text {rd }}$ campaigns and Hospital Espanhol on the $3^{\text {rd }}$ campaign) to extremely dirty (Porto da Barra on the $2^{\text {nd }}$ campaign) (Table 6). Porto da Barra presented the highest density of items overall $\left(1.27\right.$ items $\left./ \mathrm{m}^{2}\right)$, as well as the highest mean value of densities $(0.65$ item $\left./ \mathrm{m}^{2}\right)$, followed by the Hospital Espanhol beach $\left(0.39 \mathrm{item} / \mathrm{m}^{2}\right)$ and, lastly, the Farol da Barra beach $\left(0.25\right.$ item $\left./ \mathrm{m}^{2}\right)$.

Table 6: Density of items and classification of the sampled beaches according to their degree of pollution.

\begin{tabular}{lccc}
\hline & $\begin{array}{c}\text { Density } \\
(\text { items/m }\end{array}$ & CCI & Classification \\
\hline Porto da Barra & & & \\
$09 / 22 / 2012$ & 0.54 & 10.80 & Dirty \\
$02 / 06 / 2013$ & 1.27 & 25.30 & Extremely dirty \\
$02 / 14 / 2013$ & 0.15 & 3.00 & Clean \\
\hline Hospital & & & \\
Espanhol & & & \\
$09 / 22 / 2012$ & 0.46 & 9.10 & Moderate \\
$02 / 06 / 2013$ & 0.73 & 14.50 & Dirty \\
$02 / 14 / 2013$ & 0.00 & 0.00 & Clean \\
\hline Farol da Barra & & & \\
$09 / 22 / 2012$ & 0.63 & 12.60 & Dirty \\
$02 / 06 / 2013$ & 0.09 & 1.80 & Very clean \\
$02 / 14 / 2013$ & 0.05 & 1.00 & Very clean \\
\hline
\end{tabular}

\section{DISCUSSION}

The most abundant categories of items were plastic, wood, metal and fabric. The plastic category was the most abundant in two of the three sampled beaches and was only surpassed by the wood category at the Porto da Barra beach. This prevalence was also observed by CarvalhoSouza and Tinoco [15] for rocky bottoms in the Todos os Santos Bay, in which the beaches sampled in the present study are comprehended. The same authors found a density of approximately $0.1 \mathrm{item} / \mathrm{m}^{2}$, which differed from the total mean density observed in the present study $\left(0.43 \mathrm{item} / \mathrm{m}^{2}\right)$, but was close to the densities observed at Porto da Barra after Carnaval and at Farol da Barra before the event.

The proximity of the transects to the coast seemed to have influenced the type of litter found, which was identified as being originated mainly from land-based activities. This was made clear by the presence of barbecue and ice cream sticks that, in the vast majority, despite being made of wood, were in excellent conservation state, indicating a recent arrival and deposition in the local benthic environment. The presence of paper and cardboard items in all beaches is also an indicator of the proximity to the local source of pollution, given the rapid degradation of this material in seawater.

Carvalho-Souza and Tinoco [15] suggest that the similarity in the composition of litter found in the different locations they assessed could suggest connectivity among them. Thus, the material could transit among the different locations until finding favorable conditions for deposition. Considering that significant differences were not found $(\mathrm{p}>0.05)$ regarding the quantity of items among the beaches and campaigns, this could be the case in the present study. However, it is important to note also that these beaches present similarities in their characteristics regarding their use, proximity to port and industrial activities, and their insertion in the urban context. Nevertheless, despite these similarities, there were discrepancies, such as the case of a large concentration of wooden items at Porto da Barra, which could indicate local 
origin and little mobility, at least in a short term, of the local benthic litter. Thus, the similarity in the composition could reflect characteristics of the adjacent beach, added to transportation by means of currents and tides.

The day after Carnaval, February $14^{\text {th }}, 2013$, unlike what was expected, presented the lowest values of litter occurrences. However, it is important to note that there were other groups formed by volunteers carrying out cleaning activities on this day in the same area. Keeping in mind the great impact a large event such as Carnaval has on the accumulation of litter, there has been an increasing culture to carry out clean-ups after the festivities, as a way to expose this negative impact to the environment and demand actions from the authorities. Moreover, the tide during the activity was a falling spring tide, which would have a greater potential to remove and transport lighter and more recent items, which were not yet constrained by any obstacle, towards a more offshore location.

On February $6^{\text {th }}, 2013$, the rising neap tide could have collaborated in the retention of newly arrived residue in the environment. During this campaign, Porto da Barra and Hospital Espanhol were classified as extremely dirty and dirty, respectively. Only Farol da Barra presented a low pollution level on this date, and was classified as very clean. This could be explained by the fact that this beach has lower usage levels, both by beach-goers and by salespeople. The same location was classified as dirty only on September $22^{\text {nd }}, 2012$.

Another important factor to consider is the potential that benthic litter has in imposing risks to bathers' and divers' safety, which means that marine litter could be considered to be a public health issue. There was a large amount of sharp wooden sticks used for barbecues, as well as fragmented aluminum cans and pieces of glass, in the sampled beaches, and this imposes a potential risk of wounds to the beachgoers and general users of this area. In addition to these items, lost fishing gear composed by lines and hooks also present the risk of perforation. Divers can also become entangled in cables and fishing lines.

The type and intensity of use of the coastal zone adjacent to the sampled area reflected on the

different types of litter that were found, as well as on the degree of pollution of the local benthic environment. Thus, direct actions that seek to raise awareness and improve the management of the coastal zone are fundamental in preventing the input of new debris in the system and also mitigating the impacts that they impose once they are in the marine environment. It is also necessary to carry out a differentiated effort regarding awareness and encouraging good-practices among the people that sell food and beverages in the area, stimulating them to manage the residue they create in their activity better. It is important for them to understand their role and responsibility in generating residue and pollution, and not justify their behavior transferring their responsibility to the beach users, as observed in other studies [19].

\section{CONCLUSION}

According to the degree of pollution by benthic marine litter, the Porto da Barra beach was classified as dirty, very dirty and clean, respectively in the first, second and third field surveys; the Hospital Espanhol beach was classified as moderate, dirty and clean, respectively in the first, second and third field surveys; the Farol da Barra beach was classified as clean in the first field survey and very clean in the remaining surveys.

Plastic predominated among the sampled items in the Hospital Espanhol (51.69\%) and Farol da Barra (68.18\%) beaches. At Porto da Barra beach, the occurrence of wood (barbecue and ice cream sticks) $(47.57 \%)$ predominated.

The results found in the present study suggest local sources of litter to the marine environment and low mobility of benthic litter in the studied beaches. Thus, preventive measures such as providing environmental awareness to beachgoers and street vendors and installing garbage bins could reflect in the reduction of benthic pollution in these environments. 


\section{ACKNOWLEDGEMENTS}

G. Fernandino and C.I. Elliff thank the National Council for Scientific and Technological Development (Conselho Nacional de Desenvolvimento Científico e Tecnológico - CNPq) for the master degree grants. I.R. Silva thanks CNPq for her research productivity grant. All authors thank all the volunteer divers and the Galeão Sacramento diving school for the logistic support for the project.

1 Jewett SC. Pollutants of the northeast Gulf of Alaska. Mar Pollut Bull. 1976;7(9):169.

2 Feder HM, Jewett SC, Hilsinger JR. Man-made debris on the Bering sea floor. Mar Pollut Bull. 1978;9(2):52-53.

3 Harms J. Marine plastic litter as an artificial hard bottom fouling ground. Helgoländer Meeresun. 1990;44:503-506.

4 Galgani F, Burgeot T, Bocquene G, Vincent F, Leaute JP, Labastie J, Forest A, Guichet R. Distribution and abundance of debris on the continental shelf of the Bay of Biscay and in Seine Bay. Mar Pollut Bull. 1995;30(1):58-62.

5 Moore SL, Allen MJ. Distribution of anthropogenic and natural debris on the mainland shelf of the Southern California Bight. Mar Pollut Bull. 2000;40(1):83-88.

6 Lee DI, Cho HS, Jeong SB. Distribution characteristics of marine litter on the sea bed of the East China Sea and the South Sea of Korea. Estuar Coast Shelf S. 2006;70:187-194.

7 Goldberg ED. Diamonds and Plastics are Forever? Mar Pollut Bull. 1994;28(8):466.

8 IBGE. Censo demográfico - Salvador [Internet]. 2013 [cited 2013 May 10]. Disponível em: http://www.ibge.gov.br/cidadesat/topwindow.htm?1.

9 Santana Neto SP, Silva IR, Cerqueira MB, Tinoco MS. Perfil sócio-econômico de usuários de praia e percepção sobre a poluição por lixo marinho: Praia do Porto da Barra, BA, Brasil. Rev Gest Cost Integ. 2011;11:197-206.

10 Pruter AT. Sources, quantities and distribution of persistent plastics in the marine environment. Mar Pollut Bull. 1987;18:305-310.

11 Spengler A, Costa MF. Methods applied in studies of benthic marine debris. Mar Pollut Bull. 2008;56:226-230.

12 Backhurst MK, Cole RG. Subtidal benthic marine litter at Kawau Island, north-eastern New Zealand. J Environ Manage. 2000;60:227-237.

13 Revill AS, Dunlin G. The fishing capacity of gillnets lost on wrecks and on open ground in UK coastal waters. Fish Res. 2003;64:107-113.

14 Katsanevakis S, Katsarou A. Influence on the distribution of marine debris on the seafloor of shallow coastal areas in Greece (eastern Mediterranean). Water Air Soil Pollut. 2004;159:325337.

15 Carvalho-Souza GF, Tinoco MS. Avaliação do lixo marinho em costões rochosos na Baía de Todos os Santos, Bahia, Brasil. Rev Gest Cost Integ. 2011;11:135-143.

16 Cheshire A, Adler E, Barbiere J, Cohen Y, Evans S, Jarayabhand S, Jeftic L, Jung R, Kinsey S, Kusui T, Lavine I, Manyara P, Ooesterbaan L, Pereira M, Sheavly S, Tkalin A, Varadarajan S, Wenneker B, Wesrphalen G. UNEP/IOC Guidelines on Survey and Monitoring of Marine Litter. UNEP Regional Seas Reports and Studies; 2009. 117 p.

17 Alkalay R, Pasternak G, Zask A. Clean-coast index - A new approach for beach cleanliness assessment. Ocean Coast Manage. 2007;50:352-362.

18 Chiappone M, Dienes H, Swanson DW, Miller SL. Impacts of lost fishing gear on coral reef sessile invertebrates in the Florida Keys National Marine Sanctuary. Biol Conserv. 2005;121:221-230.

19 Dias-Filho M, Silva-Cavalcanti JS, Araujo MCB, Silva ACM. Avaliação da Percepção Pública na Contaminação por Lixo Marinho de acordo com o Perfil do Usuário: Estudo de Caso em uma Praia Urbana no Nordeste do Brasil. Rev Gest Cost Integ. 2011;11(1):49-55. 